Artículo. Rocío Rodríguez Ferrer. "La literatura mirable: La Lira Popular chilena como escopo"

\title{
LITERATURA MIRABLE: LA LIRA POPULAR CHILENA COMO ESCOPO ${ }^{1}$ SEEABLE LITERATURE: THE CHILEAN LIRA POPULAR AS SCOPE
}

\author{
Rocío Rodríguez Ferrer \\ Pontificia Universidad Católica de Chile \\ rcrodrif@uc.cl
}

\begin{abstract}
RESUMEN:
Las siguientes páginas exponen una lectura de la Lira Popular chilena desde su particular configuración como escopo, es decir, como un singular objeto gráfico al que se observa y se atiende al constituir toda una experiencia visual. Literatura que salta a la vista, provoca y demanda la mirada del público (lector, espectador) desde una doble visualidad: en tanto imagen (tipo)gráfica e imagen encarnada en el lenguaje. Se propone, en definitiva, aportar una nueva arista a la comprensión de los mecanismos texto visuales de la Lira, examinando no solo sus reconocibles estampas, sino, y muy especialmente, relevando la palabra plástica y la inventiva visual como clave retórica.
\end{abstract}

PALABRAS CLAVE: Lira Popular chilena, escopo, visualidad

ABSTRACT: The following pages present a reading of the Chilean Lira Popular from its particular configuration as a scope, meaning, a singular graphic object that can be observed as constituting a visual experience. This is a literature that jumps into view, provoking and demanding a public gaze (reader and viewer) from a double visuality: it is a (typo)graphic image and an image incarnated in language. This article seeks to contribute a new angle to understanding the textual-visual mechanisms of the Lira, by examining not only its recognizable features, but rather, by revealing the plastic word and the visual invention as rhetorical essentials.

KEY-WORDS: Chilean Lira Popular, scope, visuality

Recibido: 01 de junio de 2020

Aprobado: 30 de junio de 2020 
En clara afinidad con los requerimientos de una sociedad post Revolución Industrial que demandará “...la aparición de un material tipográfico más vistoso” (Corbeto y Garone 154), la Lira Popular chilena emergió con una notable capacidad: golpear visualmente a un público no del todo alfabetizado o no tan habituado a la lectura, hasta el punto de convertirse en un fenómeno editorial-impresor en el Chile del siglo XIX. Respondiendo a una poética oculocéntrica (Jay 2007), las hojas de poesía popular impresa hicieron del reclamo óptico, en su reiteración multiforme, una seña de identidad en su inscripción urbana; artificio escópico el de la Lira Popular que nos permite hablar, como veremos, de una notoria -siempre el ver- vocación exhibicionista, en sintonía con la cultura decimonónica. Voluntad y deseo de ser vistos que los pliegos de Lira evidencian y conquistan más allá de la materialidad tipográfica, en un completo y coherente mecanismo iconográfico. $^{2}$

La de la la Lira Popular fue una propuesta icónica doble: la de las estampas (clichés y grabados populares) que vuelven los pliegos reconocibles por su fijación óptica y la de una inventiva visual como marca retórica. ${ }^{3}$ Estas hojas volantes de poesía popular impresa se erigieron (desde 1865 aprox.) como una suerte de poesía mural -efímeramente mural- ${ }^{4}$ asentada en diversos espacios de encuentro y tránsito: fondas, chinganas, estaciones de ferrocarriles, calles, plazas, mercados y puestos callejeros. Con su peculiar modo de

\footnotetext{
${ }^{2}$ Una primera y restringida aproximación al tema la abordé en el artículo "Codificaciones visuales de la Lira Popular chilena del siglo XIX: sobre la retórica monstruosa y su reclamo óptico" (2017). En dicha publicación me centro, desde un ejemplo concreto, en el modo en que los discursos teratológicos se valen del requerimiento visual, al definirse y reconocerse el sujeto monstruoso, muy especialmente, por el sentido de la vista. Otras cuestiones relativas a la configuración material de la Lira las he abordado, desde una perspectiva trasatlántica, en el artículo "Poesía de cordel española y Lira Popular chilena: una lectura desde la materialidad y su apropiación popular" (2014).

${ }^{3}$ Con respecto a las estampas de la Lira, es deseable contar algún día con un repertorio digital de sus materiales iconográficos y tipográficos, en la línea del trabajo realizado por Mercedes Fernández Valladares desde la biblioiconografía en torno a pliegos sueltos españoles. Ello facilitaría lecturas más fundamentadas, pienso, sobre las características de dichos clichés y grabados populares, así como de sus formas de utilización por parte de los puetas populares; lecturas, por ejemplo, como la realizada por Tomás Cornejo en sus "Notas para comprender las imágenes de la Lira Popular", donde ahonda en el carácter referencial de las imágenes, a modo de íconos, y, de modo muy preciso, en el vínculo entre las xilografías populares y ciertas imágenes de la cultura oficial (los retratos presidenciales).

${ }^{4}$ Sigo aquí a José Simón Díaz y los trabajos posteriores de Rosario Consuelo Gonzalo García, quienes subrayan que “...lo que va a definir a la poesía mural es su condición de poesía orlada” (Gonzalo 754). Estampas y juegos tipográficos son parte de esos recursos ornamentales característicos de la poesía mural. Pero si la poesía mural del Siglo de Oro se hacía mural en el entramado arquitectónico (758), la Lira lo hará, en sentido amplio, en el entramado urbano.
} 
Artículo. Rocío Rodríguez Ferrer. "La literatura mirable: La Lira Popular chilena como escopo"

instalación urbana, entonces, la Lira Popular saltaba a la vista, al empapelar la ciudad de versos que, en efectiva sinestesia performática, convocaban tipos impresos, imágenes, canto y voceo.

En su especial querencia por la vista, la Lira Popular obliga a suspender los criterios eminentemente textualistas. Desde su condición de particular objeto tipográfico promueve un primer contacto visual marcado por la simultaneidad: las habituales estampas cobijadas en una sola plana difieren el recorrido de la lectura, al que se accedería tras la sucesión propia de la representación verbal. También al no haber paginación (un pliego extendido, sin doblez alguno), se ve favorecida la simultaneidad característica de la percepción visual. ${ }^{5}$ Pero los requerimientos ópticos van más allá y emergen desde la propia tipografía: titulares y textos llamativos, con letras grandes y variadas. Una tipografía apropiada para impresos de grandes dimensiones, como puede admirarse también en periódicos y carteles de la época. Tipos modernos propiciados por la Revolución Industrial (Corbete y Garone 155) y que, en su afán de incorporación, hacen de la Lira una suerte de muestrario de la variedad de letras surgidas en el siglo XIX. ${ }^{6}$

Tomemos como ejemplo el siguiente pliego de José Hipólito Cordero (figura 1). Podremos admitir fácilmente que los titulares, con su variedad de fuentes, también deben ser comprendidos a modo de imagen; forman parte del decorado, tal como los filetes entre columna y columna que hacen de la hoja volante atomizada en su puesta en página (y similar a la vista a un periódico). Un área considerable dentro del pliego da cobijo a la xilografía -tallada a punta de navaja en madera de raulí- y al titular de la hoja volante, con lo que este pareciera desempeñar un rol llamativo antes que informativo, “...primero 'visto' e incorporado como imagen y luego leído" (Malacchini 98). La querencia por la vista emerge otra vez.

\footnotetext{
${ }^{5}$ Suscribimos aquí a Michael Baxandall, de la mano de Guiseppina Ledda: "Remito y hago propio cuanto señala Michael Baxandall cuando, a propósito de la simultaneidad del acceso al objeto visual y de la linealidad y sucesión de su representación verbal, distingue en el proceso perceptivo un primer momento de fijación óptica, en el que el objeto se ofrece in toto, y quien lo mira recibe el bosquejo de un conjunto, de una escena, de un cuadro que, a continuación, en la sucesiva observación de los detalles, se precisa con gradual nitidez" (240).

${ }^{6}$ Una documentada e iluminadora investigación sobre la Lira Popular desde el diseño gráfico la lleva a cabo Simoné Malacchini. Coincidimos con ella en que la tipografía en estos pliegos es utilizada también como imagen (146).
} 


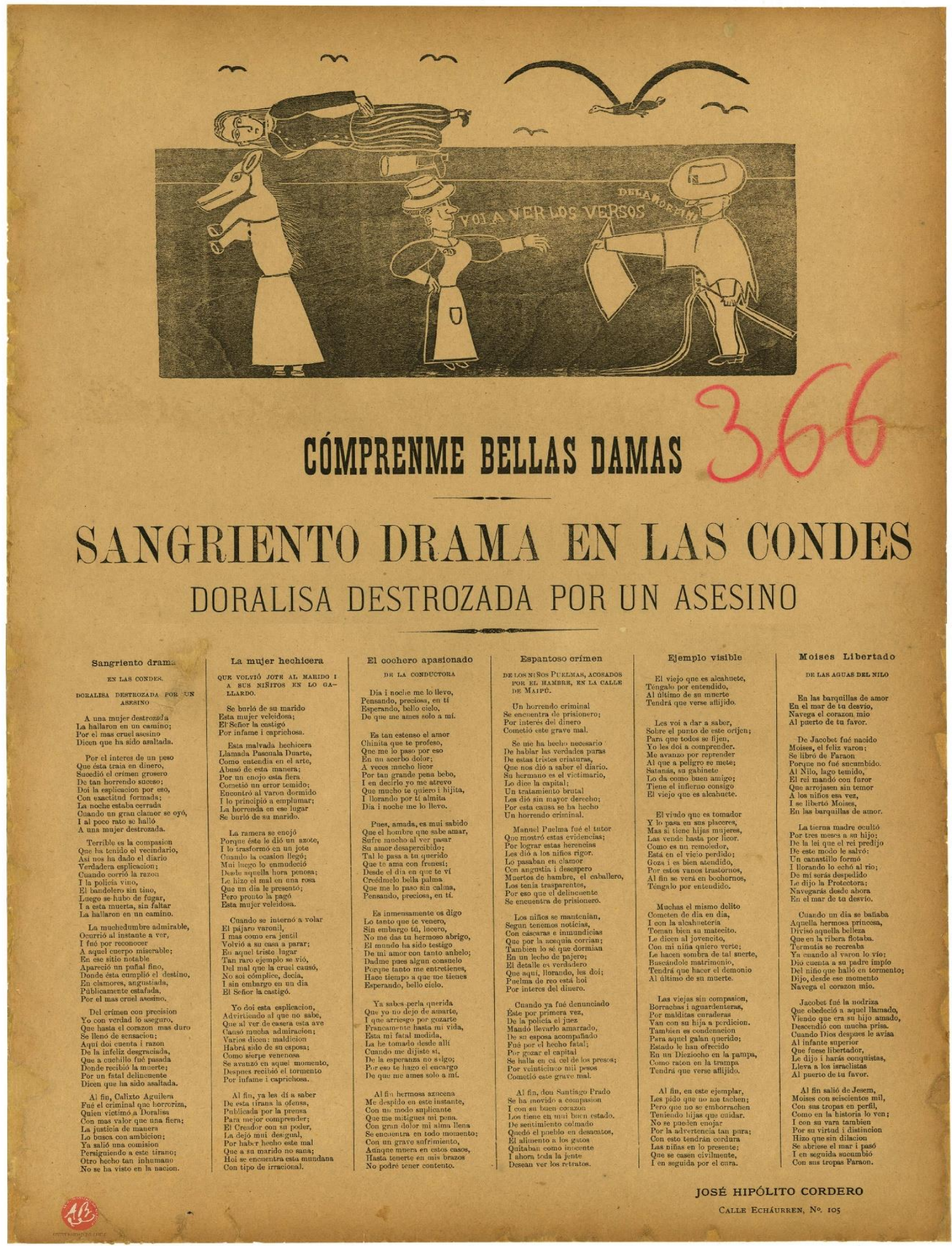

\section{[FIGURA 1]}

José Hipólito Cordero, colección Raúl Amunátegui, 366, Archivo Central Andrés Bello, Universidad de Chile (366 C794b Caja N4b, Tomo II). 
Artículo. Rocío Rodríguez Ferrer. "La literatura mirable: La Lira Popular chilena como escopo"

Tan peculiar estética parece responder también, una vez más, a una realidad común al horizonte tipográfico decimonónico a nivel internacional:

. . . los diversos diseños de los que disponía un impresor eran empleados muchas veces de manera simultánea, generando un verdadero collage tipográfico, una combinación que hoy tal vez nos parecería poco ortodoxa pero que gustaba mucho en el siglo XIX. Esta tendencia al exceso y al barroquismo visual empezó a decaer a partir de la segunda mitad del siglo, aunque los tipos de gran anchura y peso no dejaron de ser usados por los diseñadores e incluso los artistas de vanguardia recurrieron a ellos para elaborar muchos de los carteles y pinturas que se realizaron en las primeras décadas del siglo siguiente (Corbeto y Garone 159)

Horror vacui y collage, como veremos líneas abajo, son modos de referir la estética de la Lira por parte de algunos críticos (Alamiro Ávila 6), una estética de carácter acumulativo que, en su exceso, genera la sorpresa. Y con una fascinación por la imagen afín a la de las vanguardias artísticas. Pero detengámonos, por ahora, en la mención a los carteles. Porque de ellos parece profitar la Lira, tanto en lo que a visualizaciones escenográficas como a representaciones estereotipadas se refiere. O, como señala Eduardo Castillo, puede que estemos, más bien, ante un anuncio de dicho arte, si se consideran los distintos niveles de lectura e impacto visual sugeridos por la totalidad: “. . . pueden ser aproximaciones importantes para señalar a las liras como uno de los precedentes del cartel en Chile, cuando el letrero dominaba las fachadas del naciente comercio urbano, y mucho antes de que la publicidad impresa se hiciera extensiva al espacio público en forma masiva" (32-3). ${ }^{7}$ De cualquier modo, está claro que Lira y cartel coinciden en el tiempo de la civilización de la imagen, “...cuyos primeros pasos para su consecución se dieron en el cambio decisivo en la relación del sujeto respecto al campo visual social que se produjo a finales del siglo XIX, cuando masas urbanas e imágenes entraron en un estado de mutua fruición"; una época en la que la imagen ostenta una ubicuidad tal que explica su capacidad colectiva de atención (Rodríguez de la Flor 26-7).

\footnotetext{
${ }^{7}$ En la misma línea, afirma Malacchini: “Quizás la Lira Popular bien pudo ser un antecesor al 'cartel', dado el protagonismo de la imagen en una gran parte de las hojas. En relación a esto, los pliegos que poseen grandes imágenes de cuadros antiguos, perfectamente podrían haber sido una equivalencia y un 'acercamiento popular' a los libros ilustrados que en la época eran muy costosos, y a los cuales este público mayoritariamente no tenía acceso" (71).
} 
Nueva Revista del Pacífico 2020, Nº 72, (pp. 173-191). ISSN (e) 0719-5176

Pero en la Lira Popular también la palabra es imagen. Y es que de tanto insistirse, el mirar se reviste de expresividad. ${ }^{8}$ No sorprende entonces que en la primera décima encuartetada ("Sangriento drama en Las Condes. Doralisa destrozada por un asesino") aparezcan ya claras menciones al ver: "La muchedumbre admirable, / Ocurrió al instante a ver, /I fué por reconocer /A aquel cuerpo miserable". ${ }^{9}$ Nuevamente será una ponderación incitadora de asombro la que comparezca en la composición siguiente, el verso titulado "La mujer hechicera que volvió jote al marido i a sus niñitos en Lo Gallardo": "Que al ver de casera esta ave /Causó mucha admiración". Y ante el "Espantoso crímen de los niños Puelmas, acosados por el hambre, en la calle de Maipú”, “... ahora toda la jente /Desean ver los retratos": lo escabroso del acontecer aguijonea el sentido de la vista.

Por otro lado, el "Ejemplo visible" -el título lo dice todo- será el modo hallado por el pueta para advertir al viejo alcahuete de las aflicciones que le esperan llegado el momento de morir. El contar, entonces, significa mostrar. El discurso poético procura poner ante los ojos, hacer ver, los diversos motivos o fundamentos. Y para ello, es crucial el énfasis en la percepción sensorial. El de la Lira -sobre todo aquella referida a crímenes, monstruosidades y prodigios, calificada en su retórica como tremendista- suele ser un discurso marcado por el desbordamiento de los sentidos, confiriéndole al texto una recreación realista y un dramatismo patético: "Por el interes de un peso/ Que ésta traia en dinero/Sucedió el crímen grosero./De tan horrendo suceso;/Doi la esplicacion por eso,/Con exactitud formada;/La noche estaba cerrada/Cuando un gran clamor se oyó/I al poco rato se halló/A una mujer destrozada" ("Sangriento drama..."). ${ }^{10}$ La insistencia en los sentidos corporales (vista, oído) dispensa a la palabra una nítida visualidad que, sumada a la iterativa deixis demostrativa ("a aquel cuerpo miserable", "en este sitio notable", "donde ésta cumplió el destino" ...), sugiere una demostración visual, un relato teatralizado, con un decorado específico delineado por estas suertes de didascalias o indicaciones verbales para

\footnotetext{
${ }^{8}$ Aunque referido a la creación áurea española, destaco la contribución de la lectura del artículo de Ignacio Arellano "Valores visuales de la palabra en el espacio escénico del Siglo de Oro". Entre otros mecanismos de visualidad implícita en la palabra, Arellano menciona, entre otros, los verbos videndi, la deixis demostrativa y los valores cromáticos de un texto (411).

${ }^{9}$ Tanto en esta como en las demás transcripciones mantengo la ortografía original.

${ }^{10}$ En el ya referido artículo sobre las codificaciones visuales, me refería al tremendismo como estética reconocible en la Lira, tal como se vislumbra también en la literatura de cordel española y que, entre otros, ha trabajado María Sánchez Pérez. Aunque lo dejo para futuras investigaciones, creo que este afán crudelista cabría leerse a su vez en sintonía con la estética decadentista, tan del gusto finisecular y contemporáneo, pues, a la Lira.
} 
Artículo. Rocío Rodríguez Ferrer. "La literatura mirable: La Lira Popular chilena como escopo"

el montaje. ${ }^{11}$ Pero también en la estampa o grabado popular podemos reconocer esa conformación didascálica: es una impresión detenida de la puesta en escena, una impresión instantánea y congelada en un siglo fascinado precisamente con la fotografía. ¿O no nos sugiere también la xilografía de este otro pliego de José Hipólito Cordero (figura 2) la visualización escenográfica idónea para el contrapunto entre el despachero y el tomador?

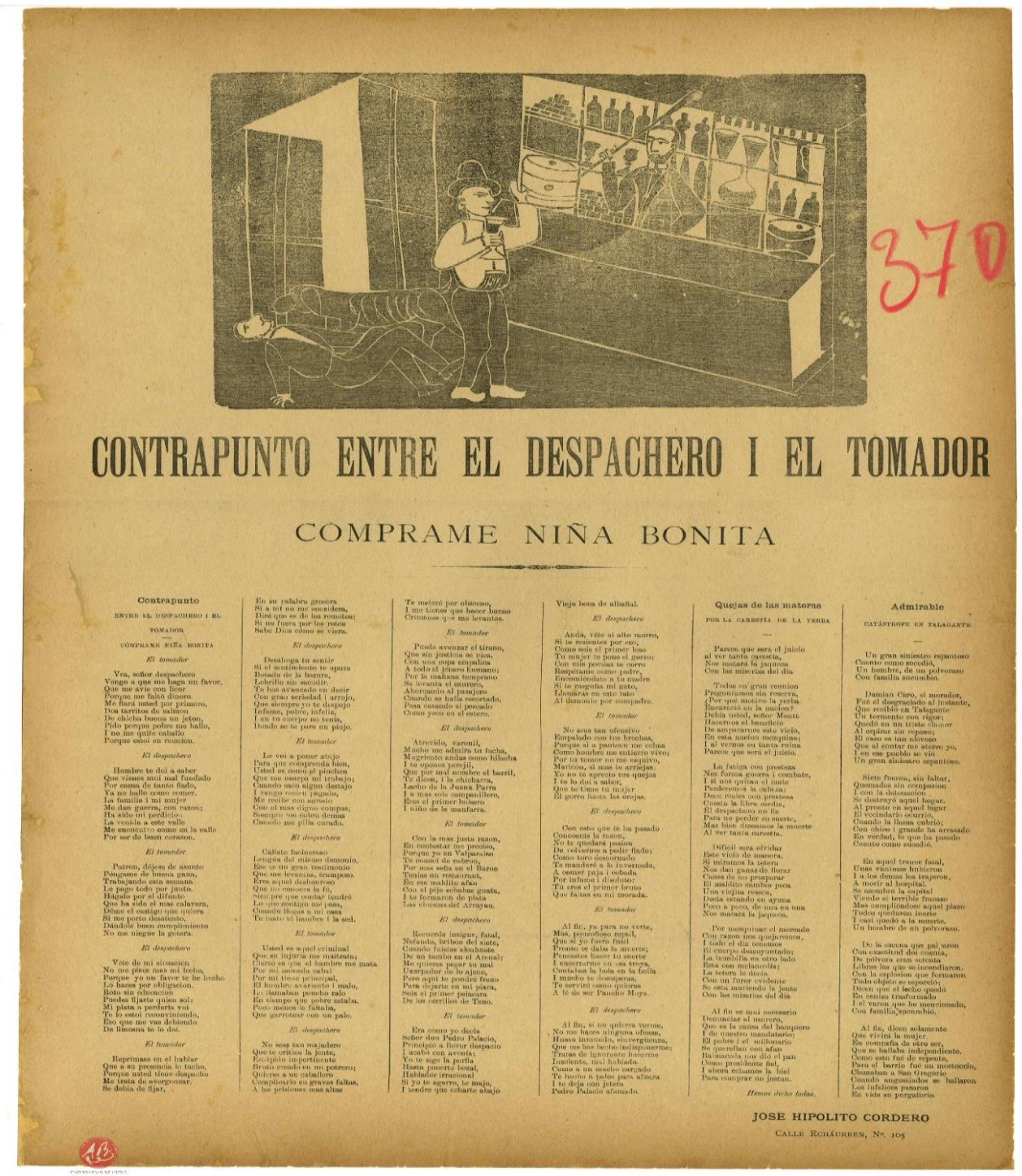

[FIGURA 2]

José Hipólito Cordero, colección Raúl Amunátegui, 370, Archivo Central Andrés Bello, Universidad de Chile (370 C794c Caja N4b, Tomo II)

\footnotetext{
${ }^{11}$ Sobre las didascalias implícitas dirá Arellano que “...más que describir, ponderan los aspectos visuales de la escenografía..." (415). Y más adelante: “...estas didascalias exigen, implican una puesta en escena, una visualización material, y provocan en la lectura la visualización imaginativa" (427).
} 
La presentación de esa escena en sus rasgos fundamentales (qué, quiénes y dónde) permite ya una lectura rápida, sintética, concentrada y acotada del hecho narrado-poetizado. Una imagen fija, un esquema o bosquejo de la anécdota, suerte de fotografía noticiosa cobijada en la portada de un diario, que aproxima el discurso literario de la Lira al registro periodístico. Si además atendemos al hecho de que la Lira coincide temporalmente con la irrupción en Chile del mundo de la ilustración, resulta evidente que en la puesta en página el grabado refuerza la exhibición, al facilitar el avistamiento del motivo poético, con el valor de vivacidad y efecto de presencia considerado inherente a las imágenes, que acaban por integrarse al entorno como un objeto más (Freedberg 50; Rodríguez de la Flor 34).

A través de la palabra poética se genera una visualidad reforzada por la representación de los detalles materiales en los grabados populares realizados ex profeso para la hoja volante. ${ }^{12}$ Si tanto en el caso del descuartizamiento de Doralisa como en el de la mujer hechicera (figura 1) el desenlace implica una apoteosis visual ("Que hasta el corazon más duro /Se lleno de sensacion", "Que a cuchillo fué pasada”, "Otro hecho tan inhumano/No se ha visto en la nacion" --- "El Creador con su poder,/ La dejó mui desigual,/Por haber hecho este mal/Que a su marido no sana;/ Hoi se encuentra esta mundana/Con tipo de irracional.”), esta [la apoteosis visual] emerge ponderada en el pliego al ofrecer detalles más concretos y de mayor precisión visual: la mujer de mirada triste, carente de un brazo y presentada junto a su pierna mutilada, en un gesto casi surrealista, se nos revela, inequívocamente, como Doralisa. Pájaros rodean la composición, como aquellos jotes en los que han sido convertidos el marido y los hijos de la hechicera de la segunda décima glosada. Y de ellos pareciera escapar -según sugiere la dirección de su cuerpo, su línea visual- ese ser híbrido, mitad equino mitad hembra, hechicera veleidosa que, por castigo divino, se halla "con tipo de irracional": la locura y maldad reflejada en una

\footnotetext{
${ }^{12}$ No desconozco las particularidades que supone la imagen realizada ex profeso si se la compara con el empleo de un cliché reciclado. Pero me aboco a la primera no solo por su importancia gráfica para la identificación de la Lira como un específico género editorial. También lo hago siguiendo criterios cuantitativos: "En relación a la presencia de la imagen en los pliegos de la Lira, se constata tanto en la Colección Lenz como en la Colección Alamiro de Ávila que en la mayoría aparecen grabados xilográficos. En una segunda jerarquía están los grabados en metal o clichés. Finalmente, en pliegos posteriores, se incorporará con mayor frecuencia el uso de fotograbado. La presencia de algún tipo específico de imágenes dependería, además de las posibilidades técnicas del lugar de impresión, de la decisión del autor del pliego (el poeta), como también de aquellas tomadas por el tipógrafo e impresor según el material que hubiese a disposición” (Malacchini 111).
} 
Artículo. Rocío Rodríguez Ferrer. "La literatura mirable: La Lira Popular chilena como escopo"

fisonomía animalesca que es, al mismo tiempo, castigo y aviso, es decir, otro exemplum visible, uno que lleva a pensar, aunque sea superficialmente, en alguna huella trazada desde la frenología o la fisiognomía, tan en boga en aquellos años en Chile y que, desde el imaginario médico, nos hablan también de la importancia de la imagen. Como fuere, la impresión de inmediatez es innegable y, gracias además a la enunciación interpelante ("Yo doi esta esplicasion/Advirtiendo al que no sabe"), perfilando en nosotros receptores casi una postura y una voz del hablante, se nos impele y orienta la mirada.

Con un lenguaje que glosa el grabado con abundantes notificaciones escópicas, la Lira Popular, de uno u otro modo, se liga a una espectacularidad. Podríamos decir que somos convocados a recepcionar la Lira en condición de observadores, de fisgones de un discurso dramático que se actualiza en un montaje. ¿Cómo leer, si no, esa xilografía (figura 1) que sitúa en escena a "El cochero apasionado de la conductora" con la leyenda "Voi a ver los versos del amor fino"? Formulación lingüística de futuro que pone ante nuestros ojos, en una suerte de juego metaficcional o metavisual, a la voz poética de la tercera décima como proyección del pueta que exhibe para la venta su hoja de versos. El texto poético, entonces, se vuelve acontecimiento visual tanto por el componente iconográfico como por el lenguaje apelativo propio del mundo dramático. La virtualidad teatral se hace patente además en la súplica del cochero apasionado y dado al alcohol y al llanto (en clave melodramática), todo un diálogo potencial que leemos en la cuarteta: "Dia i noche me lo llevo,/Pensando, preciosa, en tí/Esperando, bello cielo,/De que me ames solo a mí”. Una conductora es su objeto de deseo que, para sumar juegos a la concreción visual, es referida en términos que captamos, otra vez, por la vista: lucero, cielo, perla, azucena...

La representación de este diálogo quejumbroso se teatralizaría, además, ya desde la invocación de los suplementeros a cargo de la venta y propagación de la hoja de Lira bajo la fórmula "vamos comprando, vamos pagando, vamos leyendo, vamos vendiendo"-tras la que seguiría el pregón en voz alta del título y las materias del pliego, con el grito de cierre “¡Los versos! ¡Los versos!” (Lenz 573). Recurriendo al imperativo verbal, tan caro al teatro (“Cómprenme bellas damas"), el versero insiste en la comprensión del pliego como un objeto material, con el lógico ofrecimiento a la vista que supone. El pliego es, en sí, un escopo: un objeto al que se mira y atiende y, como buen objeto eminentemente visual, llena nuestra percepción en un momento (Moxey 130), como si tuviese vida propia. La Lira 
Popular es, ante todo, una literatura mirable que exhibe un espíritu histriónico, que explica que el pliego acabe convertido en escenario y sus consumidores, obligados a comparecer y situarnos como esa audiencia interpelada. ${ }^{13}$

Que las hojas de Lira hagan gala de una pulsión histriónica no resulta extraño en una centuria como la del XIX signada por la ostentación y exhibición en los comportamientos, como es el caso de las tertulias efectuadas incluso en la vía pública. Tal como explica Javier Guerrero: “...si la exhibición es el género decimonónico preferido, entonces el exhibicionismo es el género dominante del siglo XX y quizás también del XXI. La exhibición requiere de objetos exhibibles, aunque se trate de cuerpos, personas enfermas, órganos, etc." (49); la Lira sería pues, ese objeto exhibible. Referido al Chile decimonónico, se ha llegado a hablar de una efervescencia del arte escénico (Subercaseaux, Piña), de una inclinación espectacular manifestada, incluso, en los fusilamientos convertidos en teatros de la muerte, de los que también, por cierto, participaban los poetas populares componiendo pliegos que servían de acompañamiento a dicha "función pública". "Las representaciones escénicas fueron el objeto de consumo cultural por excelencia de las clases dominantes" (Catalán 82), pero también, con sus propias variantes, de las clases populares. Desde esta perspectiva, podríamos llegar a leer la Lira Popular como una modalidad afín, en su reclamo por ser vista, a los géneros chicos teatrales. O incluso asemejable en su atomización y serialización material al "teatro de tandas", al "teatro por horas" o por sesiones. ${ }^{14}$ No por nada la experiencia de la fragmentación en la percepción es característica de la modernidad (Crary 11).

Refuerza esta propuesta interpretativa el que también en los teatros, como el Teatro Popular levantado por el intendente Benjamín Vicuña Mackenna, se dieran lugar las contiendas entre los puetas (Eugenio Pereira, en Piña 71). Y si las astracanadas fueron de las modalidades preferidas del público chileno, no debiese de sorprendernos que uno de los

\footnotetext{
${ }^{13}$ Como ha señalado Jonathan Crary al hablar de percepción y espectáculo en la cultura moderna: "En apariencia, hay varias razones por las que la temática de la obra es potencialmente escénica: no sólo muestra una actuación casi teatral, sino que sitúa al espectador como parte de una audiencia frente a un espacio parecido a un escenario" (182-3).

14 "Los públicos populares disfrutaron, desde 1888 hasta el inicio del siglo siguiente, del surgimiento, consolidación y decadencia del género chico, organizado como teatro por secciones" (Piña 87). La gran adhesión de público con que contó la zarzuela, por ejemplo, también se explicaría por el éxito del sistema "por tandas" (Piña 95).
} 
Artículo. Rocío Rodríguez Ferrer. "La literatura mirable: La Lira Popular chilena como escopo"

mejores cultores de la Lira Popular, a mi juicio, el Rómulo Larrañaga que firma como Rolak entre las diversas identidades literarias que se crea -otra mascarada que suena a teatro-, dé forma a un género único en la poesía popular impresa: las rolakadas, es decir, las "bromas de Rolak", sus invenciones disparatadas y ridículas. ${ }^{15} \mathrm{Y}$ podríamos seguir identificando proximidades entre la Lira Popular y los géneros chicos: la presentación de tipos, más que de personajes complejos; la comicidad del lenguaje, la expresión popular...En definitiva, también los verseros formaron parte del bullicioso ambiente teatral y estuvieron familiarizados con la espectacularización. Que no de otra manera hemos de entender, además, el plano performativo de la difusión (voceada, declamada, cantada...) de sus pliegos sueltos. La imagen es, sin duda, uno de los lenguajes del teatro, y la poesía, al exigir la mirada, al volverse objeto del spectare, se arrima al arte escénico (Cancelliere).

Vemos en estos ejemplos que la xilografía ocupa un área considerable dentro del pliego, como suele suceder en la mayoría de las hojas de Lira de disposición vertical (Malacchini 109). La factura en madera explica los trazos gruesos de los grabados. ${ }^{16}$ Como arte de contornos (Plaza 164), la xilografía origina una estética algo tosca en sus figuras, a la que también contribuye en intensidad el juego contrastivo blanco-negro (y que hace frente, a su vez, con el cromatismo verbal de los versos). Con singulares tamaños y disposiciones corporales, carentes de perspectiva, los grabados populares optan por destacar los elementos más significativos para el reconocimiento del mensaje: la pierna desmembrada, la hibridez desfigurante, el papel en el que el enamorado vierte sus lamentos...El gesto corporal trasluce cierta teatralidad, cierto dinamismo, a pesar del congelamiento de lo gráfico. Y cierta ingenuidad asimilable a la plástica infantil (esquematización, desproporción o proporción significativa...) explica el calificativo de naif que muchas veces han merecido estas creaciones. Una gráfica con aire infantil que, como ha señalado Vicente Plaza, suscita un efecto de calcomanías o figuras recortables. El

\footnotetext{
${ }^{15}$ Véanse, por ejemplo, los pliegos 254 y 783 de la colección Raúl Amunátegui, resguardada por el Archivo Central Andrés Bello de la Universidad de Chile.

${ }^{16}$ Para profundizar, puede consultarse Carolina Tapia (2012: 86 y ss.). Mientras trabajaba en la redacción de estas páginas, llegó a mis manos un nuevo artículo de Carolina Tapia (2018), centrado en el análisis de la narrativa visual de las estampas de los pliegos de Lira como estrategia de difusión y medio de información. En él, Tapia Valenzuela se refiere a la Lira como un fenómeno visual (123), pero lo hace desde el específico aporte de las estampas, en clara sintonía con su formación como historiadora del arte, vinculándolo a la cultura emblemática. Como prueba de la necesaria interdisciplinariedad a la hora de estudiar la Lira, nuestra mirada releva, muy especialmente, el carácter plástico-teatral del lenguaje de estas hojas impresas. Necesario ejercicio el leer estas y otras investigaciones en términos de complemento y no de carencia.
} 
espacio destinado a la estampa, con esta configuración casi a modo de collage a la que hemos hecho mención antes -a raíz también de la confluencia de variadas tipografías-, podríamos equipararlo, desde esta lógica, a aquella cartulina en la que, de forma acumulativa y a veces arbitraria, se da cobijo a diversas pegatinas.

Los aspectos señalados hasta el momento no son, por supuesto, exclusivos de estos ejemplos, pues obedecen en gran medida a unos condicionantes materiales que explican la hermandad visual entre las hojas, la forma más o menos estandarizada, codificada, sin por supuesto, negar excepciones. Prueba también de este estilo gráfico distintivo es, por ejemplo, la hoja anónima y carente de titular que contemplamos a continuación (figura 3).

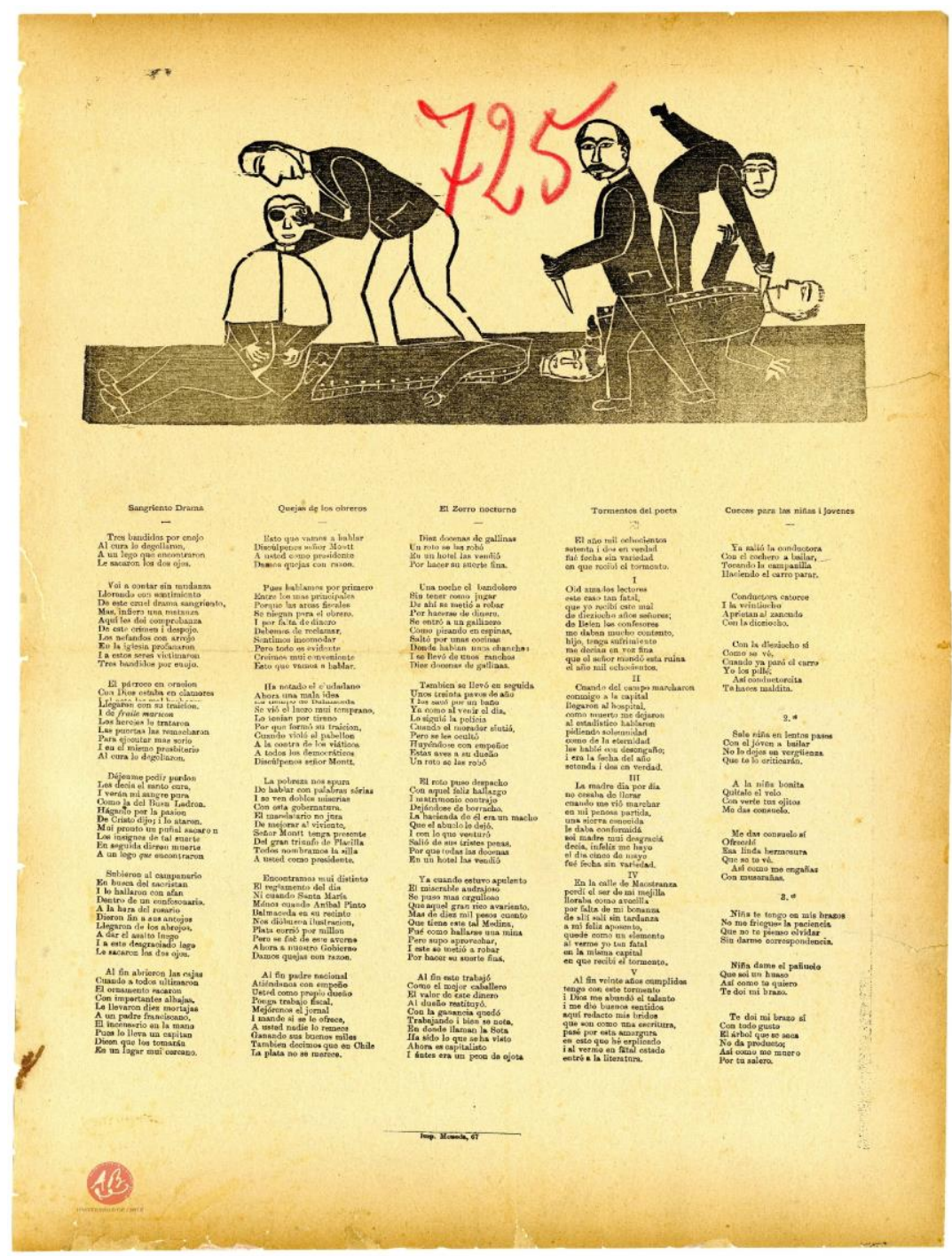

[FIGURA 3] 
Artículo. Rocío Rodríguez Ferrer. "La literatura mirable: La Lira Popular chilena como escopo"

Sin registro de autor. Colección Raúl Amunátegui, 725, Archivo Central Andrés Bello, Universidad de Chile (725 S226 Caja $\mathrm{N}^{\circ} 12^{\mathrm{a}}$, Tomo I)

Tres criminales y tres víctimas religiosas se nos presentan de modo expresivo. El detalle del cuchillo y su gestualidad convencional no deja lugar a dudas, como tampoco la decapitación ni las vestimentas de los atacados. Pero quiero ahora direccionar la mirada hacia la primera dupla, destacada en el pliego por el juego de blancos. Vemos, aquí, el aprovechamiento sensible de las posibilidades técnicas que ofrece el arte xilográfico; exagerando las dimensiones del ojo y tiñéndolo de negro, se nos sugiere lo que nos explicita la cuarteta: "Tres bandidos por enojo/Al cura lo degollaron,/A un lego que encontraron/Le sacaron los dos ojos". Desde las posibilidades rudimentarias que brinda el tallado de la madera, desde sus recursos austeros (Rodríguez-Plaza 2002: 95), la realidad poética es plasmada de modo expresionista, hasta el punto de presentar afinidades iconográficas con grabados vanguardistas, como también ha notado Carolina Tapia (2012). De carácter hipnótico hablará Pedro Millar, en tanto Alamiro de Ávila se referirá a un realismo mágico en los grabados de la Lira. No es este, claro está, el momento para juzgar comparativamente el valor estético de ambas producciones, pero sí quisiera dejar constancia de que mientras gran parte de la crítica se ha referido al grabado popular chileno señalando la tosquedad como una debilidad de ellos, en el caso de muchas de las obras del expresionismo alemán se ha reconocido un efecto de singular belleza en la técnica primaria y un elogiado gesto de rechazo al academicismo en esa buscada estética esencial. De cualquier modo, está claro que la preponderancia de la función expresiva por sobre la representativa, con esa notoria exageración de las dimensiones -toda una hipérbole visual, en el decir de Carrere y Saborit- y una lógica de la selectividad otorgan un aire de familia a estas producciones.

$\mathrm{Y}$ ya que hablamos de vanguardia, aunque rastreables desde siglos, parece pertinente sacar a la luz un excepcional ejemplo de carmina figurata que hallamos en una de nuestras Liras (figura 4). Casi un ejercicio caligramático en la plasmación de esta silueta textual; Arturo Prat elevado a la categoría de poema para mirar. O, en la expresión de Víctor Infantes, "la poesía experimental antes de la poesía experimental” en su disposición plástica y formal (2015: 46): 


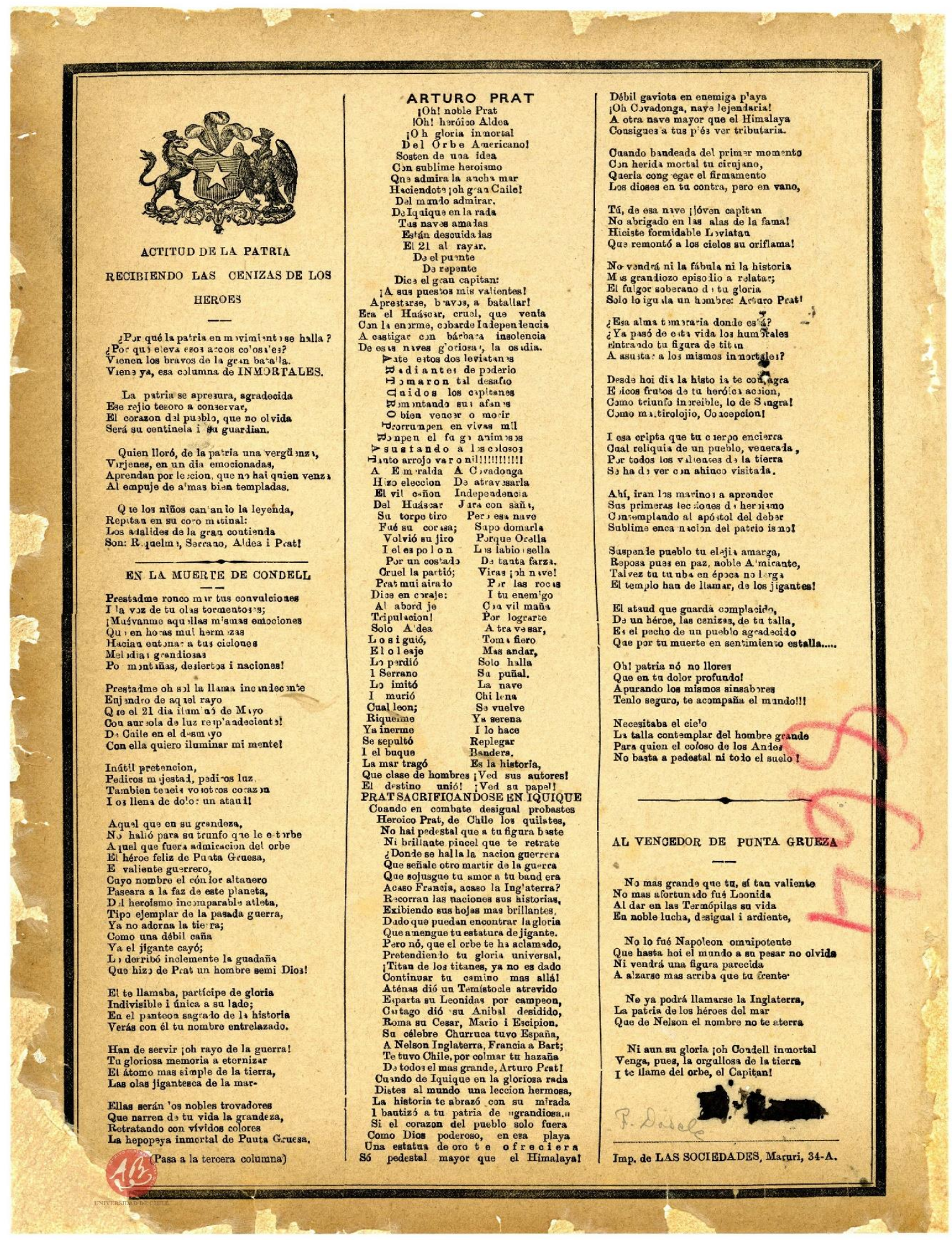

\section{[FIGURA 4]}

Sin registro de autor. Colección Raúl Amunátegui, 864, Archivo Central Andrés Bello, Universidad de Chile 
Artículo. Rocío Rodríguez Ferrer. "La literatura mirable: La Lira Popular chilena como escopo"

(864 R774a Caja N99a Tomo I)

Ahora bien, en la función iconográfica reconocemos también un sello comercial. No olvidemos ese "Cómprenme bellas damas" que, a modo de pie de foto, releva el carácter de mercancía que conlleva la Lira. Indicio de ello es también la dirección que aparece en el extremo derecho inferior de los dos primeros pliegos (“Calle Echáurren, $\mathrm{N}^{\circ} 105$ ”, figuras 1 y 2), que localiza uno de los centros de venta de la hoja volante: el domicilio del poeta. En sintonía con otro producto gráfico como es el póster o cartel, como hemos dicho, la hoja de Lira posee un tamaño lo suficientemente grande para ser avistada a lo lejos, lo que también podríamos leer en tanto guiño publicitario, en la admitida relación moderna entre exhibición y consumo (Crary).

Exhibición y énfasis son las notas características de estas hojas volanderas que, con indiscutible vocación pública, empapelan y sonorizan la ciudad con tirajes de hasta 8 mil ejemplares, según dato que aporta Rodolfo Lenz. Tanto es así que, cuando en torno a la década de 1930 decline su producción y no pocos hablen de su desaparición, señalarán que "no se oyen en las calles la publicación de sus versos" (Acevedo Hernández 53). Su silencio en los espacios de sociabilidad urbana es señal de su extinción, tal como su existencia y popularidad se constata en términos de su presencia física. Así, al menos, lo reconocemos en las líneas que Pedro Balmaceda le dedica a modo de homenaje a Bernardino Guajardo, uno de los más renombrados puetas populares, a quien da forma desde la contemplación y la escucha (e incluso, desde el olfato):

una mala imprenta daba a luz sus canciones. El anuncio de la nueva poesía de Guajardo circulaba por la mañana, en la plaza de abastos, a la hora de las cocineras, y a la tarde, se podría observar a un grupo de hombres, acurrucados en un rincón cualquiera de una calle o de un edificio en construcción, con el cigarro prendido y leyendo pausadamente, como para saborear hasta la menor idea, el sentimiento más insignificante de su pequeño Homero.

(...)

¿Nunca lo oísteis declamar sus versos? ¿Nunca visteis su cabeza blanca?

Leer una de sus estrofas es leer un pedazo de la vida del pueblo. Declamaba sus versos, que tenían todo el perfume de un manojo de flores silvestres. 
Hoy ha concluido su tarea. Ya no se verán más por las calles los papelitos de colores firmados por Bernardino Guajardo (103).

Verdadero arte urbano, escaparate también de la opinión pública, recepcionada a veces al vapor (Poblete 129-130), con celeridad, como el arte que se inscribe en la calle, la Lira Popular propicia una visión de barrido y una especial recepción en estado de distracción, en el decir de Benjamin (Crary 11). Con una topografía que refuerza su peculiar carácter mirable (sitios visibles y de circulación), la Lira Popular se yergue cara al público. Los sujetos en la calle estaban expuestos a ella, pues la ciudad, convertida en feria ambulante, es decorada por ella. En su entrega a la exteriorización, las hojas de Lira se graban en la urbe, especialmente en lugares de tránsito, en espacios del anonimato, con lo que rompe el monopolio de la élite y la alta cultura sobre los objetos visuales. Poesía a la intemperie que se deja ver: esa es la poesía popular impresa chilena. Como buen escopo, como buena literatura mirable, es en el espacio (Rodríguez de la Flor 35). Manifestándose en el ámbito de lo urbano se yergue, en su conjunto, como una suerte de graffiti o epigrama no sujeto a los muros. ${ }^{17}$ Lo dice Víctor Infantes refiriéndose a pliegos de cordel españoles: "fueron habitantes efímeros de los muros (y en ocasiones compañeros del graffiti y del pasquín)” (2006: 356). La Lira Popular, así leída, forma parte de la tribu del arte callejero, tal como lo comprende Patricio Rodríguez-Plaza: “.... se puede vislumbrar un entendimiento de la pintura callejera en general -el graffiti, los picturo-graffiti, las pintas, los tags, las plantillas o los esténciles-, así como de todo otro acto que imprime una marca visual en la carnadura de la ciudad, no necesariamente en un muro, aunque sea el soporte de espacio público más evidente" (2011: 86). Me gusta pensar la Lira, en su gusto por callejear, como parte de la estirpe de las literaturas patiperras (Rodríguez Ferrer 2014: 149), en esa expresión tan típicamente chilena, estampándose en la piel y la médula de la ciudad.

\footnotetext{
${ }^{17}$ En referencia a la práctica del mural en Chile, especialmente importante a partir de la década de 1960 , Eduardo Castillo afirma: “... los murales visualizan distintas representaciones del mundo popular y sus actores sociales: campesinos, obreros, mineros, empleados. Al predominio de la figura humana y del detalle de rostros y manos, se sumaba el entorno característico de cada grupo. Práctica no menos importante fue la satirización de los grupos hegemónicos, sentados alrededor de mesas abundantes, o recogiendo las ganancias del trabajo. Lo anterior, encuentra alguna cercanía en la mirada sobre las elites que expresaban las ilustraciones de La Lira Popular, así también el trabajo de José Guadalupe Posada, destacado grabador mexicano que influyó ampliamente en el muralismo de su país, y en particular sobre la obra de Diego Rivera." (68)
} 
Artículo. Rocío Rodríguez Ferrer. "La literatura mirable: La Lira Popular chilena como escopo"

Inscrita en el campo visual, la Lira Popular respondería a lo que Jean- François Botrel ha denominado imaginatura, es decir, “...la expresión con imágenes, de manera exclusiva o predominante, de alguna idea o historia en soportes varios, para una lectura e interpretación sui generis. Un objeto bastante distinto de la ilustración gráfica, ya que de tener un carácter subalterno o subsidiario, en la imaginatura, la imagen se vuelve el elemento principal y definitorio" (214). Compuesta sobre la base de un lenguaje escriptovisual, su autor, el pueta, no es sino un imaginero que, siguiendo el principio del decoro, exige un lector sensible a parámetros visuales. Será en ese consumo visual en donde encontremos una de las explicaciones para una hoja de poesía impresa que ha recibido el calificativo de popular y que, de la mano de Fernando Rodríguez de la Flor, podríamos adscribir a aquel discurso hipermedia “...en el que el texto continuadamente se abre a dimensiones de imagen y también a paisajes auditivos" (90).

Como el ver suele conducir al deseo, espero que este recorrido orientado a la visualidad actúe al menos como un fogonazo que en algo contribuya al cruce de perspectivas que, por suerte, lleva teniendo lugar en los últimos años en torno al estudio de la Lira Popular. Pero como todo, es esta también una cuestión de mirada.

$*^{1}$ Estas páginas son fruto de un proyecto del que fui Investigadora Responsable, realizado entre marzo de 2016 y marzo de 2017, y que contó con el financiamiento de la Vicerrectoría de Investigación de la PUC, fondo Cultura y Creación Artística (CCA): "Del graffiti no sujeto a muros: la lira popular en su inscripción urbana en el Chile de los siglos XIX y XX".

\section{BIBLIOGRAFÍA}

Acevedo Hernández, Antonio. Los cantores populares chilenos. Santiago: Ediciones Tácitas. 2015.

Arellano, Ignacio. "Valores visuales de la palabra en el espacio escénico del Siglo de Oro". Revista canadiense de estudios hispánicos. Vol. 19, No. 3 (primavera 1995): 411443.

Ávila Martel, Alamiro de. Diez grabados populares chilenos. Santiago: Universitaria, 1973.

Balmaceda Toro, Pedro. Estudios y ensayos literarios. 1889. Santiago de Chile: Ediciones Universidad de la Frontera-Origo Ediciones. 2013.

Botrel, Jean-François. "De imaginatura: la adaptación escriptovisual de la narrativa en los pliegos de aleluyas". En Simposio sobre la literatura popular. 2011. Imágenes e ideas: la imaginatura, Urueña, Fundación Joaquín Díaz, Enero 2012: 213-246. 
Nueva Revista del Pacífico 2020, Nº 72, (pp. 173-191). ISSN (e) 0719-5176

Cancelliere, Enrica. "Teatro y teatralidad en las «Soledades» de Góngora”. En Actas del IV Congreso Internacional de la Asociación Internacional Siglo de Oro. Ed. María Cruz García de Enterría y Alicia Cordón Mesa. Vol. 1, 1998: 317-328.

Carrere, Alberto y José Saborit. Retórica de la pintura. Madrid: Cátedra, 2000.

Castillo Espinoza, Eduardo. Puño y letra. Movimiento social y comunicación gráfica en Chile. Santiago: Ocholibros. 2006.

Catalán, Gonzalo. "Antecedentes sobre la transformación del campo literario en Chile entre 1890 y 1920". En Brunner, José Joaquín y Gonzalo Catalán. Cinco estudios sobre cultura y sociedad. Santiago de Chile: FLACSO, 1985: 69-175.

Corbeto, Albert y Marina Garone. Historia de la tipografía. La evolución de la letra desde Gutenberg hasta las fundiciones digitales. Lleida: Milenio Publicaciones. 2015.

Cornejo, Tomás. "Notas para comprender las imágenes de la Lira Popular". Aisthesis, núm. 59, (2016): 179-202.

Crary, Jonathan. Suspensiones de la percepción. Atención, espectáculo y cultura moderna Trad. Yaiza Hernández Velázquez. Madrid: Akal. 2008.

Díaz, José Simón. La poesía mural en el Madrid del Siglo de Oro. Madrid. Ayuntamiento. 1977.

"La literatura mural”. En Culturas de la Edad de Oro. Coord. José María Díez Borque. Madrid: Editorial Complutense, 1995: 169-179.

Fernández Valladares, Mercedes. "Biblioiconografía y literatura popular impresa: la ilustración de los pliegos sueltos burgaleses (o de babuines y estampas celestinescas)". En Humanista: Journal of Iberian Studies, Vol. 21, (2012): 87-131.

Freedberg, David. El poder de las imágenes. Estudios sobre la historia y la teoría de las respuestas. Trad. Purificación Jiménez y Jerónima $G^{a}$ Bonafé, Madrid: Cátedra. 1992.

Gonzalo García, Rosario Consuelo. "El ceremonial barroco y la poesía mural: más ejemplos de literatura efímera". En Actas del IV Congreso Internacional de la Asociación Internacional Siglo de Oro. Ed. María Cruz García de Enterría y Alicia Cordón Mesa. Vol. 1. 1998: 751-762.

Guerrero, Javier. Tecnologías del cuerpo. Exhibicionismo y visualidad en América Latina. Madrid: Iberoamericana Vervuert. 2014.

Infantes, Víctor. "Historia mínima (y desde luego incompleta) de los impresos de una sola hoja. II. Los años áureos". Edad de oro cantabrigense. Anthony J. Close (ed.), 2006: 351-356.

. "La poesía experimental antes de la poesía experimental". Lyra mixta. Silva ejemplar de artificios gráfico-literarios. España: Turpin Editores, 2015: 43-61.

Jay, Martin. Ojos abatidos: la denigración de la visión en el pensamiento francés del siglo XX. Trad. Francisco López Martín. Madrid: Akal, 2007.

Ledda, Giuseppina. "Recrear la manifestación festiva "para que la vea quien no la vio y quien la vio la vea segunda vez». Cultura y comunicación visuales a través de las relaciones de fiestas públicas". En Géneros editoriales y relaciones de sucesos en la Edad Moderna. Pedro Cátedra (dir.). Salamanca: SEMYR, 2013: 231-248.

Lenz, Rodolfo. Sobre la poesía popular impresa de Santiago de Chile. Contribución al folklore chileno. Santiago de Chile: Memorias científicas i literarias, 31 de marzo de 1894. 
Artículo. Rocío Rodríguez Ferrer. "La literatura mirable: La Lira Popular chilena como escopo"

Malacchini, Simoné. Lira popular. Identidad gráfica de un medio impreso chileno. Santiago: OchoLibros, 2015.

Millar, Pedro. "La lira popular y la tradición chilena del grabado en madera", Revista de Arte $U C, \mathrm{n}^{\circ}$ 6, verano 1990: 17-21.

Moxey, Keth. El tiempo de lo Visual. La imagen en la historia. Barcelona: Sans Soleil Ediciones, 2015.

Piña, Juan Andrés. Historia del teatro en Chile 1890-1940. Santiago: Ril Editores, 2009.

Poblete, Juan. Literatura chilena del siglo XIX: entre públicos lectores y figuras autoriales. Santiago de Chile: Cuarto Propio, 2002.

Plaza, Vicente. "Grabados de la Lira Popular. Estudio del grabado del pliego Ayes i lamentos del poeta Daniel Meneses". Mapocho. Revista de Humanidades, $\mathrm{N}^{\circ} 78$, 2015: 161-176.

Rodríguez de la Flor, Fernando. Giro visual. Primacía de la imagen y declive de la lectoescritura en la cultura postmoderna. Salamanca: Editorial Delirio, 2009.

Rodríguez Ferrer, Rocío. "Codificaciones visuales de la lira popular chilena del siglo XIX: sobre la retórica monstruosa y su reclamo óptico". En Encrucijada de la palabra y la imagen simbólicas. Estudios de emblemática. Blanca Ballester Morell, Antonio Bernat Vistarini y John T. Cull (editores). Palma, José J. de Olañeta Editor (Anejos de Imago 5, Col. «Medio Maravedí» 19), 2017: 593-604.

- "Poesía de cordel española y lira popular chilena: una lectura desde la materialidad y su apropiación popular". Revista de Humanidades $\mathrm{N}^{\circ} 30,2014$ : 129165.

Rodríguez Plaza, Patricio. Pintura callejera chilena. Manufactura estética y provocación teórica. Santiago de Chile: OchoLibros Editores, 2011.

. "Imágenes, fotografía e identidad desde la Lira Popular". Aisthesis 35, 2002: 89-100.

Sánchez Pérez, María. "La retórica de las relaciones tremendistas del siglo XVI". Praestans labore Victor: homenaje al profesor Víctor García de La Concha. Javier San José Lera coord. Salamanca: Universidad de Salamanca, 2005: 217-234.

Subercaseaux, Bernardo. Historia de las ideas y de la cultura en Chile, vol. i, Santiago: Editorial Universitaria, 2011.

Tapia Valenzuela, Carolina. "Grabado popular: ¿antecedente o referente en la historia del grabado en Chile?”. Mapocho 72, 2012: 79-94.

. "La narrativa visual en las estampas de los pliegos de poesía popular chilena como estrategia de difusión". En De la pluma al internet. Literaturas populares latinoamericanas en movimiento (siglos XIX-XXI). Christoph Müller y Ricarda Musser (eds.). Medellín: Editorial EAFIT; Ibero-Amerikanisches Institut Stiftung. 2018: 119-145. 